\title{
CULTURAL ASPECTS OF SUSTAINABLE DEVELOPMENT IN TEACHER EDUCATION
}

\author{
Ilze Briška \\ University of Latvia, Latvia \\ Gunta Silin,a-Jasjukeviča \\ University of Latvia, Latvia
}

\begin{abstract}
Education for sustainable development (ESD) cannot be realized without a teacher, who thinks systematically and critically, reflects cultural and sustainable values, is authentic, self-conscious, creative, self-confident, and communicative. The aim of this study is to analyze the cultural aspect of sustainable development (SD) in education and to interpret the opportunities and risks for successful development towards the sustainability in teacher education and through the findings to make connections to general education. To reach the goal, qualitative research was conducted. The data was obtained through interviews; teacher educators were asked to share their beliefs, expectations, and experiences about the incorporation of SD into teacher education. The data were proceeded by hermeneutic analysis of text. As a result of the analysis, various combinations of study content and methods related to the cultural aspects of SD in teacher education practice were generalized. The research results identified possibilities for the development of SD through cultural aspects in teacher education.
\end{abstract}

Keywords: cultural aspect of education, sustainable development, teacher education.

\section{Introduction}

Sustainable development (hereafter: SD) is a significant issue in the contemporary world. There is a great amount of research in the natural sciences, social sciences and interdisciplinary studies related to SD. In political documents, guidelines, recommendations, and procurements, SD goals are set very high. The ambitious aims, values, desirable results, and the ways for meeting the goals of SD are clearly formulated.

The incorporation of the ideas of SD into the general school curriculum is a challenge for schoolteachers and teacher educators because the concept sustainable development is very complex and ambiguous. There is a risk that important concepts, values, and huge amounts of information can become 
a cumbersome in the construction of SD without a deeper understanding and guidelines for implementation. The responsibility of a graduate from a teacher education program is to make SD accessible and personally significant to each primary school student; that is, to make it simple and easy to grasp without losing the depth and seriousness of the topic.

Researchers acknowledge that the cultural dimension of SD encompasses all other categories of SD (Grossberg, 2010; Raus, 2018). This means that culture could be one way to relate all of the complexities of SD to each person's life and a means to enrich teacher education.

The aim of the study was to look for pedagogical opportunities related to the cultural aspects of SD in the successful development of sustainability in teacher education. To achieve this goal:

1. The concept, cultural aspect of $S D$, was analyzed.

2. The cultural aspect of sustainable development was interpreted into categories of education to highlight the tasks for teacher educators towards the meeting the SD goals.

3. Teacher educators' beliefs and expectations about SD in teacher education were investigated to find out typical mindsets and practices.

4. The structure for analysis of the manifestation of the cultural aspects of SD in teacher education was developed.

The clarified concept, cultural aspect of $S D$, will be useful for teacher educators to reflect deeper on their assumptions, beliefs, and professional practices in order to approach the SD goals purposefully.

As a result of the study, significant issues for the further research, the teaching culture and culture of educational organization are identified.

\section{Theoretical background}

Theoretical background is based on the analysis of UNECE, UNESCO documents and research related to the education of sustainable development (Barth, Godemann, Rieckmann, \& Stoltenberg, 2007; Raus, 2018; Sterling, 2010; UNECE, 2009, 2011; UNESCO, 2017). The analysis of the cultural aspects of SD is proceeded by the context of documents from the United Nations and research in cultural theory anthropology (Gertz, 1973; LeviStrauss, 2001). The issues in education are interpreted from the perspective of social constructivism (Kron, 2004), a socio-cultural approach (Bennett, Grossberg, \& Williams, 2005; Grossberg, 2010), experiential learning (Dewey, 1979; Griffin, Holford \& Jarvis, 2003; Kolb, 1984), and teachers' mind-frames (Hattie, 2009).

Sustainable development is the organizing principle for meeting human development goals, while simultaneously sustaining the ability of natural systems to provide natural resources and ecosystem services upon which 
the economy and society depends. The United Nations has formulated Sustainable Development Goals as the blueprint to achieve a better and more sustainable future for all. They address the global challenges facing humanity in economic, environmental and social aspects, including those related to poverty, inequality, climate change, environmental degradation, peace, and justice (United Nations, 2015).

The natural and social sciences provide a venue for sustainable development goals with issues such as citizenship, peace, ethics, responsibility in local and global contexts, democracy and governance, justice, security, human rights, health, gender equity, rural and urban development, economy, production and consumption patterns, corporate responsibility, environmental protection, natural resource management, and biological and landscape diversity (UNESCO, 2017). The cultural sustainability is described there in terms of cultural capital, traditions and values, heritage and place, the arts, diversity and social history (Roseland et al., 2005). Duxbury and Gillette characterize the cultural dimension of SD from the perspective of the inner relationship of the community (Duxbury \& Gillete, 2007). They stress the significance of community well-being; mutual collaboration within the community; common experiences that express a sense of place and create a source of pride for residents that increases their sense of connection with their community; an ecological way of life and production; and the use of the arts to engage community residents in common creative activities.

Within the political documents the main goals of global SD are related to economic, social, and environmental fields, but cultural sustainability is categorized there under the social pillar of SD. Whatever, with recent developments, considerations are being made to make cultural sustainability its own pillar, due to its growing importance within social, political, environmental, and economic spheres (UCLG, 2010). Soini and Birkeland explains the importance of cultural sustainability with its influential power over the people, as decisions that are made within the context of society are heavily weighed by the beliefs of that society (Soini, Birkeland, 2014).

Hawkes suggests to use the term culture in the context of sustainability to describe the social production of meaning or making sense together. In this sense, politics, economics, and ecology are cultural phenomena, and culture is a key factor for achieving a sustainable society. He points out the significance of including the cultural perspective in all public policies: "It is what gives us a guarantee that every process of sustainable development has a soul" (Hawkes, 2001, p. 25).

Anthropologists point out that humanity is created by culture and culture is created by humanity; to be human is to be cultured and, also, to be human is to differentiate oneself from uncultured nature fundamentally 
(Lewi-Strauss, 2001). Culture influences a person's attitudes, beliefs, expectations, values, identity, and practices. Underpinning each human thought is behavior and action which are present at every moment of a person's life. On the other hand, the culture establishes deep connections between an individual and values of the society.

Culture is explained in anthropology as symbolic, ideational, and intangible aspects of human society (Banks, Banks, \& McGee, 2015), "an accumulated totality of symbol-systems (religion, ideology, common sense, economics, sports, etc.) in terms of which people make sense of themselves and their world, and represent themselves to themselves and to others" (Geertz, 1973, p. 47). So, the culture has become recognized as a working antidote to overly technocratic, mechanistic means of understanding cultures (culture as learned and shared patterns of behavior), organizations, and historical settings. Culture is not a set of facts, but it is the evaluation and interpretation through a prism of an individual's personal significance and the values of the society in which they live. The culture of each community or social group is expressed in written and unwritten laws and norms. But cultural vitality can be reached only through the participation of each member in the community (Silin,a-Jasjukeviča, Briška, 2016).

Griswold differentiated four cultural perspectives: (1) culture as separated from everyday living and comprised of elevated activities and materials, such as fine and performing arts and literature; (2) culture as a coherent system, of norms, beliefs, values, and attitudes; (3) culture as a tool kit used by humans to make sense of their world; and (4) culture as a phenomenon, which affects social existence (Griswold, 2012). So, culture can be attributed to art, to individual sense, to societal norms, or to the existential reality of being a human. In education, all these approaches are familiar, but the question is, which of them are the most appropriate for meeting the SD goals.

In order to promote student's cultural understanding, educators must consider a person's subjective sense emotional experiences, the different layers of meanings, symbols, and complexities within a specific context; and an individual's openness to ambiguous interpretation (Bennett, Grossberg, \& Williams, 2005; Grossberg, 2010). Humanity's transformation, which is essential for the development of SD in education, will take place only through personally significant experiences of cultural values and subsequent actions that will transform an individual's personality and the world (Briška, 2011).

Education for sustainable development is mainly associated with learning the issues related to natural sciences (i.e., climate change, protection of biodiversity) and social sciences (i.e., development of society for all), and with respect to cultural diversity (UNECE, 2009). More recently, another 
educational aspect appears in formulations of the results of education for $\mathrm{SD}$ as competences for sustainable development - critical thinking, personal and collaborative competences (UNESCO, 2017) systems thinking, values thinking, futures thinking, strategic thinking, and complex problem solving (Raus, 2018; Sterling, 2011). The concept of competence in itself means a deep involvement of the personality. Halupa explains that, in the case of transmissive learning, the highest level of achievement in learning is concluding, interpreting, and estimating. In contrast, the transformative learning results are internalization and displaying one's knowledge i.e., competence (Halupa, 2016). Her statement is supported by the opinion of other authors (Bennett, Grossberg, \& Williams, 2005; Grossberg, 2010; Kron, 2004).

Theoretical sources dealing with a learner's personal transformation include approaches of experiential learning and in-depth learning. Experiential learning develops the idea of including the learner's personal and cultural experiences into the educational process (Dewey, 1979; Griffin, Holford \& Jarvis, 2003). The result of deep learning is not only cognition, but a transformed person. This approach deals with the opposition between concepts of in-depth and surface cognition. Surface deconstructs structure, perceiving all phenomena of culture as equally significant or in one layer (Shusterman, 2002; Welsch, 2005). UNECE experts point out that the development of SD competences is fostered in education by a holistic approach that seeks integrative thinking and practice, inclusivity, and deals with complexities as well as envisioning change while exploring alternative futures (UNECE, 2011).

Therefore, the objective and critical explanations of cultural phenomena are not enough for the deep learning of culture; but the learner's subjective sense must be involved in study process. If it is personally meaningful human transformation can occur. The purposeful cultivation of the cultural aspect in teacher education helps to make learning the multilayered and contradictious content and competences of SD organic, vital, personally meaningful and transformative (Siliņa-Jasjukeviča, G. Briška, 2016).

To educate the teachers to be the agents of sustainable development in educational communities, the SD topics, students deep personal involvement, openness to mutual contexts should be incorporated in study process.

\section{Methodology}

To recognize and develop the theoretical findings of the cultural aspect of sustainable development in the current teacher education practice, the qualitative study was carried out. The data was obtained in semistructured interviews with teacher educators. 
Respondents were asked to what extent and how they address SD goals in their teaching practice, how they do it, how it could be done better, and how important it is in their study course and the teacher education in general. The cultural aspect of SD was interpreted in interviews through beliefs, values, expectations, personal preferences, and meanings attributed by teacher educators to the cultural aspect of sustainable development. Hermeneutic-analysis was chosen as the method to analyze the interviews because "the hermeneutic makes possible to understand the sense and the deepest sense of a text" (Vieira, Queiroz, 2017, p. 14).

Interviews were transcribed and read several times. The units of meaning were coded freely individually by two experts. Then the interpretations were discussed to group the codes in accordance with the theoretical findings, by relating them to the content of SD, focus of students' individual sense and experiences in study process, and context of studies.

The codes not fitting with these categories were grouped separately for additional analysis.

Twenty-five teacher educators, all academic staff from preschool and primary school teacher education department were interviewed between October and December, 2019.

\section{Results and Discussion}

One group of codes emerged by marking the SD topics - ecological balance, economic and social well-being as study content. They were generalized from teacher educators' statements like, "teachers need science-based, pragmatic knowledge at the level of values." They believed that the content of learning should raise i.e., "awareness of the role of the teacher as a agent of change in promoting sustainable development." They added that "SD key themes can be analyzed in a narrower and broader sense, at the level of the individual or humanity." Some interviewees pointed out that the study process matters - "discussions and researches of motives and consequences of ones or humans actions, evaluating them in the context of SD key topics are very helpful, such activities should rise further teachers' awareness, change their mindset and professional habits."

Some respondents directly mentioned that vitality, liveliness, and organicity are essential values. Others nominated the special courses devoted to sustainable development goals as environmental science, economics, ecology and ethics, or integrating particular topics in didactic courses such as the didactic of natural sciences, social sciences, design and technology, for example, "recycling the trash", "global warming", "children rights" and like.

In the second group, the codes related to the respondents' beliefs in the significance of promoting the growth of a future teacher's personality 
as a responsible, reflective, and self-developed person were united. This idea was interpreted in expressions which characterized the study process like "personally meaningful learning", "involving students in the process of in-depth analyze", "transformative learning is like an organic and neverending flow that deeply changes everybody who is involved in this process", "student's self-development", "inspiring students for self-education", and "discussions, personally meaningful questions - that makes the study process valuable and inspiring." The call for improvement of future teachers' selfawareness through the reflection of personal emotional experiences was qualified as the "high esteem for student individuality."

The third group of codes related to the contexts of education, mentioned by respondents. There were codes that nominated the significance of various perspectives or points of view: "the teacher's message in different levels of education must be realized in a broader perspective, not just a narrow focus on the content of a particular school subject", "subject (Language, Visual Arts, Math, etc.) matters only if we understand its meaning in a wider - socio-cultural context...". The diversity, openness, critical thinking, and civic responsibility were named as significant values in educators' expressions.

Additional codes were fixed on particular contexts of studies including childhood experiences, local community, traditions, outdoor learning, actual situation - the contexts of life outside the textbook, school, and individuality. It is interesting to note than no one's responses were related to the context of the future of the planet or humankind.

Thus, all three components of theoretically substantiated SD cultural aspects in education were found in interviews. It means, that the established theoretical structure is valid for application in practice. Meanwhile, teacher educators' combine the components in different ways by placing emphasis on the content of SD and in this way students' personal transformation or mutual interconnections between sociocultural contexts is experienced.

There were one group of codes, which did not fit in any of three previously expected categories. It related to the relationship between participants of education - teacher - student, student - student, teacher - teacher. There were some critical statements made by the interviewees: "cooperation between colleagues and also with students are not very satisfactory. To be true, there are few of us who generate ideas and make decisions for all, others just agree. I think it is still Soviet heritage and this must be overcome if we want to truly take care of qualitative education for SD". Negative attitude towards the student as a partner in study process were apparent: "Students do not have independent learning skills. They are reluctant to follow the teacher's instructions". Additionally, there were positive attitudes about the collaboration i.e., "I have learnt from 
the students so much", or "the new generation is more open than ours", and "Self-development is promoted by cooperation and the opportunity to share discoveries with others." This group of codes allows to add another component to the pre-defined cultural aspects of SD in teacher education. In addition to the studies, respondents have paid close attention to the culture of the educational institution - a set of beliefs and values that determines all the traditions, symbols, rituals, attitudes, perceptions of the desired behavior and performance and human relationship in school (Fullan, 2007).

The results of the data analysis are generally structured in Figure 1.

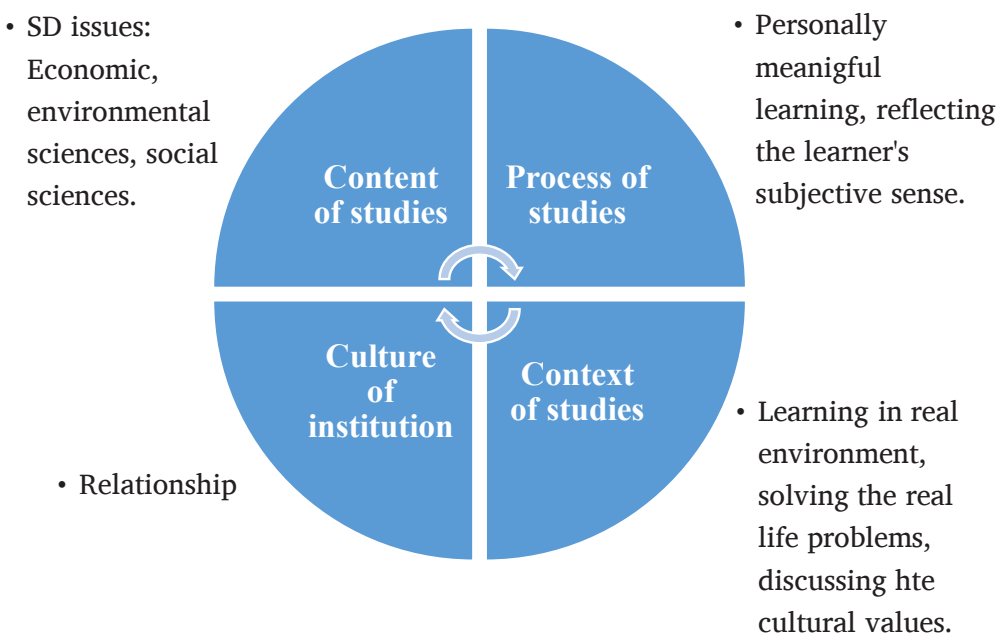

Figure 1. Development of the cultural aspects of SD in teacher education.

The structure of the pedagogical means for approaching to the meeting the SD goals in teacher education contains four components. Each of them reveals the questions, which helps the educator to do it purposefully:

How to include the economic, environmental, social and political issues in each study course?

How to make student's learning personally meaningful by engaging individual's actual life and reflecting the subjective sense?

How to engage the mutual contexts of real life and different cultures?

How to cultivate the relationship or education stakeholders?

\section{Conclusions}

Culture connects the values of society and the experiences of an individual. Without a deep personal experience, the declared values 
of SD stay at a superficial level. Individual wellbeing and self-expression without the understanding of content of SD does not lead to the personal transformation. Culture is a framework that helps makes the movement toward SD possible.

The cultural aspect of SD teacher education can be realized by:

- Discussing the meaning/significance of the key topics of SD in each study discipline and inter-disciplinary.

- Rating the students' personal experiences of cultural meanings - vitality, equity, viability, responsibility, innovations, creativity, and focusing on the organic balance between the life (environment protection) and human well-being (economic and politics).

- Promoting the students and staff members reflection on their values experiences and cultural contexts of learning in all study courses.

- Strengthening the students' SD competencies such as values thinking, critical thinking, system thinking, creativity, and cultural awareness in personally meaningful learning.

- To enrich the study process and culture of institutions with diverse forms of participation and collaboration.

Teacher educators' combine the components in different ways by placing emphasis on the content of SD and in this way students' personal transformation or mutual interconnections between sociocultural contexts is experienced.

The reflection on teacher educational practices from the perspective of the unity of the cultural aspect of SD is helpful in determining the opportunities and risks for each individual teacher educator in each unique situation for the efficient realization of the education for SD.

Strengthening the cultural aspect helps teacher education approach the ideals of sustainable development in a transformative not only in formal and institutional way.

\section{References}

Banks, J. A., Cherry, A. \& McGee, B. (2015). Multicultural education: Issues and perspectives, ( ${ }^{\text {th }}$ ed.). Wiley.

Barth, M., Godemann, J., Rieckmann, M., \& Stoltenberg, U. (2007). Developing key competencies for sustainable development in higher education. International Journal of Sustainability in Higher Education, 8(4), 416-430.

Benett, T., Grosberg, M., \& Williams, R. (2005). New keywords:A revised vocabulary of culture and society. Blackwell Pub.

Briška. I. (2011). Topošo skolotāju profesionālo vērtību veidošanās mākslinieciski radošā darbībā (Development of student teachers' professional values in artistic creativity). PhD Thesis. Riga: University of Latvia.

Dewey, J. (1979). Art as experience. A Paragon Book. 
Duxbury, N., \& Eileen, G. (2007). Culture as a key dimension of sustainability: Exploring concepts, themes, and models. Creative City Network of Canada. Retrieved from https:// cercles.diba.cat/documentsdigitals/pdf/E130054.pdf.

Fullan, M. (2007). The new meaning of educational change ( $4^{\text {th }}$ ed.). New York: Teachers College Press.

Geertz, C. (1973). The interpretation of cultures. Basic Books.

Grossberg, L. (2010). Cultural studies in the future tense. Duke University Press.

Griffin, C., Holford, J., \& Jarvis, P. (2003). The theory \& practice of learning. Kogan Page

Griswold, W. (2012). Cultures and Societies in a Changing World. Pine Forge Press.

Halupa C. P. (2016). Transformative curriculum design. Retrieved from http://doi. org/10.4018/978-1-5225-0978-3.ch021

Hattie, J. (2009) Visible learning: A synthesis of meta-analysis relating to achievment. Routledge.

Hawkes, J. (2001). The fourth pillar of sustainability: Culture's essential role in public planning. Retrieved from http://www.culturaldevelopmnt.net.au/community/Downloads/Hawkes Jon\%282001\%29Th eFourthPillarOfSustainability.pdf.

Kolb, D. A. (1984). Experiential learning: Experience as the source of learning and development. Englewood Cliffs, NewYork.

Kron, F. W. (2004). Grundwissen didaktik. Ernst Reinhard Verlag.

Raus, R. (2018). Student teacher ecological self in the context of education for sustainable development: A longitudinal case study. Journal of Education for Sustainable Development, 11(2), 123-140.

Levi-Strauss, C. (2001). Myth and Meaning. Routledge.

Roseland, M. (2005). Toward sustainable communities: Resources for citizens and their governments. New Society Publisher.

Shustermann R. (2002). Surface and depth. Dialectic of criticism and culture. Cornell University Press.

Silina-Jasjukeviča, G. Briška, I. (2016) In-depth cultural studies in multicultural group. Discourse and Communication for Sustainable Education, vol. 7, Rēzekne: Rēzeknes Tehnoloǵiju akadēmija, pp. 139-148

Soini, K., Birkeland, I. (2014). Exploring the scientific discourse on cultural sustainability. Retrieved from: https://doi.org/10.1016/j.geoforum.2013.12.001.

Sterling, S. (2010). Transformative learning and sustainability: Sketching the conceptual ground. Learning and Teaching in Higher Education, 5(2010-11), 17-33.

UNESCO. (2017). Incheon Declaration and SDG4 - Education 2030 Framework for Action for the implementation of Sustainable Development Goal 4. Retrieved from https://unesdoc.unesco.org/ark:/48223/pf0000245656

UNECE. (2011). Learning for the future. Competences in Education for Sustainable Development. Retrieved from https://www.unece.org/fileadmin/DAM/env/esd/ESD_ Publications/Competences_Publication.pdf.

UNECE. (2009). Learning from each other: The UNECE strategy for education for sustainable development. Retrieved from https://sustainabledevelopment.un.org/ content/documents/798ece5.pdf. 
United Cities and Local Governments (UCLG). (2010). Culture: Fourth Pillar of Sustainable Development. Policy Statement approved by the UCLG Executive Bureau, Mexico City, 17 November 2010.

UN (2015). Transforming our world: The 2030 agenda for sustainable development. Retrieved from https://www.un.org/ga/search/view_doc.asp?symbol=A/RES/70/1\& Lang $=\mathrm{E}$.

Vieira, K. A. L., \& Queiroz, G. M. (2017) Hermeneutic content analysis: A method of textual analysis. International Journal of Business Marketing and Management (IJBMM), 2, 8-15.

Welsch W. (1996). Grenzgänge der Ästhetik. Stuttgart: Reclam. 